\title{
A FENNTARTHATÓSÁGRA NEVELÉS HIÁNYTERÜLETEI
}

\author{
Saly Erika - Néder Katalin - Varga Attila \\ Oktatáskutató és Fejlesztő Intézet
}

\section{Ökoiskolák és a fenntarthatóság}

Mitől öko egy iskola? Az ökoiskolák tudatosan vállalják föl, hogy létezésük alapja, mindennapi életük meghatározója a környezeti nevelés, a fenntarthatóság „missziója”. Az ökoiskolák iskolafejlesztő, „,iskolazöldítő” munkájuk során a jövő környezettudatosan cselekvő állampolgárait nevelik. Nem csak a tanítás-tanulás folyamatában érvényesítik a környezeti nevelés, a fenntarthatóság pedagógiájának elveit, hanem az iskolai élet minden területén, vagyis „egész iskolásan” (Európai Unió Tanácsa, 2010). Ez azt jelenti, hogy az iskola működtetése terén éppúgy, mint a gyerekek étkeztetése vagy a táborok szervezése során.

Egy ökoiskola iskolai munkája sokféle módon kapcsolódik a helyi közösséghez. A helyi környezeti értékek és problémák részét képezik az iskola pedagógiai munkájának, a helyi pedagógiai programba beágyazottan. Hatásuk oda-vissza érvényes, vagyis nyitott iskolaként müködnek, örömmel építenek külső kezdeményezésekre, mondanak véleményt, készítenek megoldási tervet egy-egy helyi probléma, fejlesztés kapcsán.

Miért fontos az ökoiskolák zászlóvivő, mintaszerepe? Hazánkban jelenleg közel 700 ökoiskola müködik. Vannak közöttük Örökös Ökoiskola címet elnyerők is, mely intézmények irányt, mintát mutatnak mind az iskola környezetének kialakításában, mind a pedagógiai munka, az épület müködése, a kapcsolatrendszer, a kommunikáció során. Ezen iskolák pedagógusai között nagy számban találunk elhivatott környezeti nevelöket, akik mentorálják iskolájuk továbbfejlődését, valamint segítik más iskolák fenntarthatóságra nevelését azzal, hogy bemutatják nekik jó gyakorlataikat. Az ökoiskolák ,húzóerőt” képeznek a közoktatási intézményrendszeren belül, vagyis zászlóvivőként élére állnak annak a folyamatnak, mely segíti, hogy minden iskolában értéknek tekintsék a fenntarthatóságot.

\section{A fejlesztés kerete}

A TÁMOP 3.1.1.-11/1-2012-0001 azonosító számú, XXI. századi közoktatás (fejlesztés, koordináció) II. szakasz elnevezésű kiemelt projekten belül „A nevelés-oktatás fejlesztése, komplex pilot programok" címü alprojektben az Oktatáskutató és Fejlesztő Intézet fenntarthatóságra nevelés témakörével foglalkozó munkacsoport általános- és középiskolák gyakorló pedagógusaival közösen, az ökoiskolák, s a fenntarthatóság értékrendjét magukénak valló iskolák támogatására készít nevelési-oktatási programot. 
A projekt megvalósítói a bevont partneriskolák pedagógusaival együtt mintegy száz innovatív, a tervek szerint a későbbiekben más iskolák számára adaptálható modult dolgoznak ki, melyek a tanulók hétköznapjaiban jelen lévő problémákhoz és örömforrásokhoz, felfedezésekhez, helyi épített, természeti és társadalmi környezethez köthetök.

A modulok témaköreinek meghatározását elsősorban a hazai és nemzetközi környezeti nevelési programok, projektek elemzését követően feltárt „hiányterületek" jelölték ki, másodsorban az ökoiskola kritériumrendszeréhez való igazodás, harmadsorban a fejlesztésbe bevont iskolák pedagógusainak jó gyakorlatai.

A tanulmányban csak a fenntarthatóság feltárt „hiányterületeinek” ismertetésére kerül sor. Példákon keresztül kerül bemutatásra, miképpen vannak jelen az iskolák életében az adott témakörök, s merre lehetne fejlödni. Azt reméljük, hogy a „hiányterületekre” való reagálás a lehetőségek megteremtésére ad módot egy-egy modul kidolgozása által. Ugyanis elképzelésünk szerint a feltárt hiányterületekre az innovatív környezeti nevelöknek, az iskoláknak, mint tanulószervezeteknek reagálniuk kell, illetve meglátni a bennük „rejlő” lehetőséget, tanulási helyzetet.

\section{Kutatás, fejlesztés, innováció}

Az ökoiskolák müködését támogató nevelési-oktatási program megalapozása céljából egy kutatássorozat kezdő lépéseként elemeztük a fenntarthatóság pedagógiája terén müködö, a hazai gyakorlatra legnagyobb hatással bíró nemzetközi (pl. Beagle, Carbon Detective) és hazai (pl. Iskolazöldítés, Szitakötő, Energiakaland) programokat.

A közel 60 projekt, program elemzését a következő szempontok alapján végeztük: időtartam, kezdeményezö, célcsoport, témakör, célok, módszerek, tanulástechnikai eljárások, eredmények/nehézségek (a program fennmaradása, kiterjesztése, hatása), kapcsolatok (bővebben Néder, Saly és Szentpétery, 2013).

Az elemzés eredményei alapján, a fejlesztés irányvonalának megállapítása céljából meghatároztuk azokat a hiányterületeket, amelyek elméleti és gyakorlati szempontból fontosak a fenntarthatóság pedagógiájának eredményessége miatt, de a környezeti nevelési programok sorában eddig nem voltak elég hangsúlyosak. Pedagógiai koncepciónk irányt mutat az innovációt végző munkatársaknak, tartalmazza a fejlesztés alapelveit, pedagógiai módszertanát, a segédeszközöket, az értékelés szempontjait, vagyis megalapozza magát a fejlesztést.

A fejlesztés alapelvei az alábbiakban határozhatóak meg:

- konstruktív szemléletmód érvényesítése (pl. felfedező tanulás, differenciálás, életszerü szituációk, problémaközpontú tanulás),

- innovatív tanulószervezetekkel való fejlesztés,

- belső motiváció elősegítése,

- hálózati tanulás, 
- módszerek sokszínüségének biztosítása (egyéni tanulási módok, stílusok, motivációk figyelembe vételével),

- életkori sajátosságokhoz igazodás.

Az innovációt, vagyis a programfejlesztési folyamatot a bevont pedagógusokkal együtt végezzük. Az innováció akkor lesz sikeres, ha meg is valósul, azaz a kidolgozott modulokat végül a napi gyakorlatban is alkalmazzák majd az iskolákban, vagyis az ökoiskola nevelési-oktatási programcsomag innovatív produktummá válik. A fejlesztést állandó visszacsatolások, korrigálások jellemzik a tanulószervezeti, s a fejlesztést végző iskolák, szakértők hálózataiban.

\section{A fenntarthatóságra nevelés hiányterületei}

Mit is jelent a „hiány”? Azt, ha valamiről már tudjuk, hogy létezik, de csak „vágyódunk” utána. Ha nincs felismerés, akkor nem is hiányzik, nélküle is megvagyunk. Ha fenntarthatóságra nevelésről beszélünk, akkor vajon mi okozhatja ezt a hiányt? Például az, ha olvasunk egy-egy témakörről, vagy kiderül egy beszélgetés során, hogy más már körbejárta a témát, de mi még nem adaptáltuk, nem vettük át a jó gyakorlatot, csak tudjuk, hogy kezdhetnénk valamit a témával, hiszen ,az utcán hever”, ott van az orrunk előtt. No, akkor már kreatív ötletek születnek az ember fejében, elkezdi foglalkoztatni a téma, a lehetőség.

Ha konkrétan megnézzük a környezeti nevelést, hogy milyen pillérekre épül, akkor tudjuk, hogy mesterséges, természetes és társadalmi környezet az, amivel foglalkoznunk kellene. Jelenleg azonban a környezeti nevelésben a felsorolt területek egyensúlytalansága jellemző. Többnyire a természetes környezetet helyezzük a vizsgálódásunk középpontjába az iskolákban. Ez némileg érthető, hiszen a gyerekeket leginkább a természet „szólítja meg”. Ezen területen belül inkább módszertanilag van „hiányérzetünk”. Ha ki is visszük a tanulókat a szabadba, a terepre („outdoor learning” - lásd Real World Learning Network projekt), nem hagyjuk őket eleget kísérletezni, kérdezni, tévedni, megfigyelni, elmélyülten átélni. Így aztán egy idő múlva „leszoknak” ezekről. A mesterséges (épített és tárgyi) környezet megismertetésére egyáltalán nem vagy csak alig szánunk időt, pedig „,benne” élünk, időnk nagy részét töltjük „városlakóként”. A társadalmi problémák embervoltunkból fakadnak, vagyis a másság elfogadása, a hajléktalanság, a mélyszegénységben élőkkel való találkozásunk, együttélésünk nehézségei, a felelösségünkről való gondolkodás, az érzékenyítés mindenképpen feladatunk. Minden mindennel összefügg. A teljességet kell megláttatni tanítványainkkal ahhoz, hogy rendszerben gondolkodjanak, megértsék az összefüggéseket, s tudjanak majd felnőttként felelősen gondolkodni, beavatkozni, döntéseket hozni.

Menjünk előre, fejlődjünk, ha felismertük a hiányt! Mi kell a fejlődéshez?

- Kreatív, kísérletező, innovatív pedagógusok,

- kíváncsiságukat megőrző, felfedező gyerekek,

- lelkesítő, biztonságos légkör,

- tanulószervezet, hálózati tanulás. 


\section{Hiányterületek}

A fejezeten belül bemutatásra kerülnek azok a hiányterületek, melyek ugyan jelen vannak a fenntarthatósági nevelésben, de nem elég hangsúlyosan, illetve nem biztos, hogy a leghatékonyabb módszertani és tanulásszervezési megközelítéssel. Minden esetben a jelenlegi helyzetkép leírására kerül sor először, majd olyan lehetőségek feltárására, melyek megvalósítása egyfajta reagálás az adott „hiányra”, vagyis önfejlesztésre ad módot.

\section{Természettudomány, fenntarthatóság, innováció kapcsolódása}

\section{Helyzetkép és lehetőség}

A természettudományos tantárgyakat tanítók többsége fontosnak tartja, hogy a fenntarthatóságra neveléssel foglalkozzon. Ehhez alapul szolgál a NAT célrendszere, a kerettanterv is. Nincs kihasználva viszont minden módszertani, s a valósághoz köthető innovációs lehetőség. P1. a megújuló energiaforrásokról, a környezetbarát technológiákról a tanulók tankönyvböl, jobb esetben honlap alapján - kutató munka során - tájékozódnak.

Mennyivel izgalmasabb, hatékonyabb lenne, ha pl. maguk tervezhetnék meg iskolaépületük környezetbarát müködtetését, átalakítását, s a közös fejlesztésbe bevonhatnák a helyi mérnököt, aki a megújuló energiaforrásokat, környezetbarát technológiákat bemutatná, akivel számításokat végeznének a gyerekek, hogy mennyibe kerülne pl. egy napkollektor felszerelése az épületre, vagy egy kerti zuhanyzó összeállítása, s mikor térülne meg a befektetés. Akár ellátogatnának egy napkollektort összeállító mühelybe ${ }^{1}$, vagy ökofaluba, ahol maguk is részt vehetnek a kivitelezésben is. Egyéb innovatív ötletek is elökerülhetnének, melyek közül egy-kettő megvalósítására is sor kerülhetne. A tanulók ebben az esetben innovációs társakká válnának, hasznosnak éreznék azt, amit eddig tanultak, látnák eredményét annak, s jobban megbecsülnék, magukénak éreznék az „eredményt”.

\section{Javaslat}

Az összefüggések keresésébe és az együttmüködésbe szükséges bevonni a környezetbarát fejlesztéseket végző, ökotechnológiákkal foglalkozó mérnököket, akik egyben támogatói is lehetnek egy-egy iskolában zajló kutatásnak. A diákok valós problémára, életszerü helyzetre keressenek megoldást, készítsenek megoldási tervet!

\section{II. Épített környezet lehetőségei. Építészetoktatás.}

\section{Helyzetkép és lehetőség}

A téma fontosságát és aktualitását jelzi, hogy Írországtól Litvániáig számos európai országban került be az építészet, mint témakör, a közoktatásba.

\footnotetext{
${ }^{1}$ http://www.nimfea.hu/programjaink/napkollektor.htm 38
} 
Kutatásunk során leginkább a finn mintát vizsgáltuk. Tény, hogy Magyarországon jelenleg kevesen és inkább csak iskolán kívüli foglalkozásokon találkozhatnak a tanulók a téma komplex megközelítésével. A tanórák közül a rajz-, valamint a technikaóra leginkább az, amely teret ad az épített környezettel való foglalkozásnak. Azonban a vetítésen, épületek rajzolásán, makettkészítésen túl kevésbé feszegetik a pedagógusok a témát. Jó esetben tanulmányi sétákon megfigyelés alapján készülnek rajzok az épületek jellegzetességeiről.

Ezernyi lehetőséget teremthetünk, ahol a diákok valóságból kiinduló tanulásban vehetnek részt, aminek alapján azt érezhetik, hogy értelme van! Kezdve attól, hogy vizsgálódásunk középpontjába a gyerekek iskolaépületét, majd az iskola helyi környezetének (kerület, település) épületeit, településszerkezetét, tereit helyezzük. A legfontosabb dolog, hogy felfedezzék egy-egy épület (pl. templom) szépségét, elképzeljék a múltját, megismerjék a történetét. A kutatás történhet riportkészítéssel, fotózással, internetes anyaggyüjtéssel. Készülhet az utcák, épületek alapján öröm-bánat térkép, mely térképet maguk a gyerekek készítik pl. az alapján, hogy illeszkedik-e egy-egy épület a városképbe, avagy sem, illetve jó állapotban van-e, jól funkcionál-e, milyen a természetes környezete. Téma lehet még: környezettudatos építészet, épületek alapanyagai régen és ma, vidéki építészet értékei stb.

\section{Javaslat}

A megismert jó minták alapján, Magyarországon is előtérbe kell kerülnie a gyermekek építészeti nevelésének, ennek lehetőségeinek megteremtésére és eszközeinek kidolgozására. Erre mostanában egyre több szakmai és civil szervezet próbálja felhívni a figyelmét a közoktatás fejlesztőinek. Pl. a KultúrAktív Egyesület $^{2}$ nagyon hasznos, tartalmas kiadványokat készít gyerekek számára a városok épített környezetének felfedezéséhez, lehetőséget biztosítva a települések természetes tereinek, zugainak megismerésére is. A Magyar Építész Kamara ${ }^{3}$ 2011 óta foglalkozik intenzíven a témával, összegyüjtötte a mintegy 30 évre visszanyúló hazai kezdeményezéseket és felvette a kapcsolatot az európai társkamarákkal. A Nemzeti alaptanterv, valamint a kerettantervek véleményezésével és az Oktatáskutató és Fejlesztő Intézettel történő személyes egyeztetések során hozzájárult a hazai építészeti oktatás legfontosabb elemeinek tantervbe kerüléséhez. A Kamara a Budapest XV. Kerületi Önkormányzat támogatásával a Hubay Tehetségpontban maga is kísérleti oktatómunkát folytat 2012 óta.

\section{Városi környezeti nevelés}

\section{Helyzetkép és lehetőség}

A városi környezeti nevelésnek, városi terepgyakorlatnak legalább akkora hangsúllyal jelen kellene lennie környezeti nevelési munkánk során, mint a

\footnotetext{
${ }^{2}$ http://www.kulturaktiv.hu/

${ }^{3}$ www.mek.hu
} 
természetközpontúnak. A városban élő gyerekeket meg kell ismertetnünk közvetlen környezetükkel, ahol mindennapi életük zajlik. Többnyire a városi iskolák tanulóit, mihelyt adódik rá mód, kivisszük a természetbe. Ez érthető. Egy városban növekvő gyerek számára ,természetes közeg” a betonozott út, az emeletes épületek, a zaj, a forgalom, a sok ember. Ha alkalmunk van rá, igen, törekszünk őt kivinni ebből a mü-közegből, s megmutatni, ráirányítani a figyelmét a természetre, az ott rejlö csodákra, csendre, harmóniára, sokféleségre. Mindemellett azonban fontos tudnunk, hogy a gyerekek felszínesen ismerik a saját életterüket, amiben nap, mint nap élnek, mozognak, alkotnak. Ráadásul rengeteg izgalmas témát „rejt” a városok zaja, fénye! Nem szabad kimerülnie abban a város megismerésének, hogy összeszedetjük a szemetet az iskola körül ennek nem sok nevelő hatása van egyébként, hiszen nem biztos, hogy a gyerekek dobálták szét a szemetet, más szemetét meg összeszedni már inkább etikai kérdéseket vet föl, amiről jó lenne beszélgetni egy-egy akció előtt -, vagy virágot, fát ültetünk, esetleg elmegyünk egy múzeumba. Ez mind fontos tevékenység, de izgalmasabbá is tehetjük, ha időt hagyunk a témára, s akár témanapot, témahetet, projektet építünk rá.

Lehetőség például a város öröm-bánat térképének elkészítése (lásd Vásárhelyi, 1997). Ezen a térképen minden örömöt, bánatot feltüntethetnek a tanulók, amire az adott városban rálátnak. Lehet ez egy szép, régi épület, egy szemetes tér, egy kis virág az utca repedésében, egy öreg fa, egy falfirka, egy szobor. A természeti környezetet vizsgálhatjuk városi körülmények között is (pl. forgalomszámlálás, levegővizsgálat, ezek összefüggései). A városi épített környezet, a házak, a terek, az utcák vizsgálata sok felfedeznivalót rejt (pl. mi mikor épült, milyen stílusban, illeszkedik-e egyik épület a másikhoz). A városi lét emberi vonatkozásainak vizsgálata elkerülhetetlen, hiszen ezernyi kérdése lehet ezekkel kapcsolatban egy városlakó gyereknek (pl. az ellátás, a szolgáltatás mennyisége, minősége, a másság, a hajléktalanság témaköre). Ne féljünk foglalkozni ezekkel! Például kipróbálhatjuk, hogy a kerekesszékkel lehet-e közlekedni a város utcáin, megvizsgálhatjuk, hogy el tudják-e intézni ügyes-bajos dolgaikat ezek a mozgássérült emberek (pl. bevásárlás, posta). A kipróbálás során az ép gyerekek megtapasztalják a nehézségeket, azonosulnak a sérült emberek gondjaival, örömeivel, az ő szemükkel is látják majd a világot, s másképp fognak viszonyulni hozzájuk. Egyéb témajavaslatok lehetnek: pl. Mely házakban éltek híres emberek? Milyen kapcsolatban voltak a természettel? Idézetekkel alátámasztani stb. Utcák, kerületek nevezetességei, térképkészítés. Város és a hulladékfeldolgozás, szemétkezelés, felelős kutyatartás. Tudatos vásárlói szokások: pláza vagy piac?

\section{Javaslat}

Fontos, hogy a témakör feldolgozásában is megjelenjen egyfajta fejlődési ív. Például a tanulók kereshetnek olyan teret a városban, aminek nincs funkciója, 
vagy elhanyagolt, $s$ oda tervezhetnek játszóteret, pihenőparkot, majd az elkészült tervet, makettet bemutathatják a döntéshozóknak. Esetleg védnökséget vállalhatnak felette. Jó esetben a döntéshozókkal sor kerülhet egy beszélgetésre, ahol a gyerekek visszajelzéseket kaphatnak a tervükről. Még jobb lenne azonban, ha meg is valósulhatna egy-egy gyerekek bevonásával, véleményének kikérésével készített terv. Ennek motivációs ereje ugyanis felülmúlhatatlan lenne, s biztosak lehetünk abban, hogy tanulóinkat további aktív állampolgárságra (cselekvésre, véleménynyilvánításra) ösztönözné.

\section{Természettudományos laborok használata}

\section{Helyzetkép és lehetőség}

A gyerek elemi léte, folyamatos fejlődése megkívánja, hogy állandóan kérdéseket tegyen föl, később, serdülőként megkérdőjelezze a világban megfigyelt jelenségeket, történéseket, s magyarázatokat, összefüggéseket keressen. Egyszerủen érteni szeretné a világot. Ehhez a vizsgálódáshoz, kísérletezéshez a pedagógusoknak alkalmat kell teremteni, időt kell szánni. Olyan alkalmat, szabad légkört teremteni, ahol kérdéseket lehet megfogalmazni, s ahol lehet kísérletezni. Úgy kísérletezni, hogy abban benne lehessen mindenféle retorzió nélkül a tévedés lehetősége. Sajnos ez a mai hétköznapi iskolai gyakorlatban nem így müködik. A kísérletezésre alig adunk alkalmat, s ha mégis, akkor nem igazi kísérletezést folytatnak a gyerekek, hanem szigorú szabályok alapján elvégzik azokat a tevékenységeket, melyek egy-egy vizsgálati eredményt megcéloznak a pedagógus folyamatos kontrollja mellett. Az egy másik dolog, hogy az iskolák többségében nincs labor, nincsenek kísérleti eszközök, anyagok. (Megjegyzem, hogy ettől még lehetne a szó nemes értelmében kísérletezni, ha valóban szeretnénk, hiszen pl. a jég olvadáspontjának megfigyeltetése is kísérlet, s az ehhez szükséges eszközök mindenhol rendelkezésre állnak, de sok helyen mégis a könyvből kell megtanulni a gyerekeknek az adatokat. Ez viszont megöli a kíváncsiságot, unalmas.)

Kétféle lehetőséget is bemutatok a laborok használatára. Az egyik a természetben zajló vizsgálatokhoz nyújt segítséget, a másik a hagyományos laboratóriumok használatát mutatja be.

\section{a) Zseblabor ${ }^{4}$}

Természetélményt leginkább a természetben lehet szerezni. A természetet - a természeti anyagokat - nemcsak bevihetjük a laboratóriumba, hanem fordítva: a labort (eszközöket, vegyszereket) is kivihetjük a szabad természetbe, és ott is elvégezhetjük a vizsgálatokat. Ehhez állított össze egy kis hordozható labort dr. Victor András, föiskolai tanár. A labor, mivel szinte a zsebünkben elfér, a Zseblabor nevet viseli. A gyerekeknek szóló „labort” korosztálytól függetlenül mindenki sikerrel használhatja. A terepen (erdei iskolában, táborban, 
kiránduláson) egyszerü, komplex természettudományi és környezetvédelmi vizsgálatokat lehet vele elvégezni (kisiskolásokkal ,varázsolni”). A zseblaborhoz tartozó munkafüzet érdekes, kísérletezésre ösztönző témákat, kérdéseket vet föl: levelek festékanyagainak vizsgálata, C-vitamin kimutatása, oxidálódó növényi festékek, növényi savak kimutatása, növények víztartalmának kimutatása, csont és kitin összehasonlítása, a talaj kémhatása, levegőtartalma, a víz felületi feszültsége, a levegő portartalma, a fehér szirmok „színanyaga”, órából tájoló stb.

\section{b) Iskolai laboratóriumok}

A TÁMOP 3.1.3 pályázaton belül került kiírásra „A természettudományos oktatás módszertanának és eszközrendszerének megújítása a közoktatásban (Öveges Program)" címü pályázati felhívás, a Laboratóriumok az iskolákban. Ennek a pályázatnak köszönhető, hogy sok középiskola rendelkezik 2012 őszétől már korszerü, felszerelt intézményi laboratóriummal, melyekhez az interneten is elérhető kísérleti, vizsgálatokat segítő anyagokat is készítettek az innovációban résztvevő pedagógusok. A környezeti nevelési, fenntarthatósági feladatok, kísérletek inspiráló környezetben, jó eszközkészlettel megvalósíthatók. A tudományos diákmunkákhoz szintén elengedhetetlenül fontosak a valóságban kipróbált kísérletek.

\section{Javaslat}

A természet „faggatása” fontos feladatunk. Motivál, innovációra sarkall, elgondolkodtat. A kísérletezés a legegyszerübb módon, eszközökkel is megtörténhet, ha erre bátorítjuk tanulóinkat. Jobb esetben labort használhatunk. Ha az iskolánkban nincs laboratórium, akkor egy tanterem is azzá válhat, ha kísérletezni szeretnénk. Olyan iskolákkal is érdemes fölvenni a kapcsolatot, ahol van laboratórium, s ahová beengednek vizsgálatokat végezni. A terepi kísérletek elvégzéséhez ajánlott egy-két Zseblabor beszerzése. A lényeg, hogy engedjük a gyerekeket kérdezni, szabadon kísérletezni, s lehessen tévedni, s újra próbálkozni!

\section{Humán-reál tantárgyak egyensúlya a környezeti nevelésben}

\section{Helyzetkép és lehetőség}

A társadalomtudományok és a környezeti nevelés kapcsolata még mindig a háttérben van. Míg az alsó tagozatos kisiskolások komplex látásmódját minden oldalról megerősíti a tantárgyi komplexitás is (adott téma minden oldalról való megközelítése), addig a felső tagozaton és középiskolában megfigyelhető, hogy a környezeti nevelést többnyire a természettudományos tantárgyakat tanító kollégák érzik magukénak. Ez viszont azt sugallja, hogy a környezeti nevelés nem mindenki feladata. Nehezíti a dolgot, hogy a környezeti nevelést sokan egyenlőnek érzik a környezet- és természetvédelemmel.

Jó példa azonban bőven akad az egyensúly megteremtésére: így például a múzeumpedagógia jó gyakorlatai, a Szitakötő ökológiai folyóirat témakörei. Egyegy témanap, projekt keretén belül lehetőség van minden oldalról megközelíteni, 
megláttatni ugyanannak a témának az érintettségét. Pl. a Ritmus témahéten lehet dalolni, ritmust tapsolni, dobolni, „esőt varázsolni” kavicsokkal, lehet számsort alkotni szabályok szerint, lehet a versek ritmusát megfigyelni, lehet a természetben ritmust keresni (pl. napszakok, évszakok, a hét napjai, hónapok). Lehet komolyan vizsgálódni, kísérletezni, számolni például a Csendes óceáni műanyag sziget kapcsán, de lehet verset írni, riportot készíteni, drámajátékot játszani, s mủanyagból hajót barkácsolni is.

\section{Javaslat}

Fontos, hogy a pedagógusképzésben minden szakon megjelenjen a környezeti nevelés, a fenntarthatóság pedagógiája. A hálózati tanulás során a környezeti nevelők átadhatják tapasztalataikat kollégáiknak, s bevonhatják a humán szakosokat is a munkába. Az iskolákban fontos egy-egy iskolai környezeti nevelési témanap, témahét, projekt tervezése, szervezése, melynek során kiderülhet, hogy mindennek mindenhez van köze, vagyis a környezeti nevelés komplex, mindenki feladata.

\section{Saját tanulói környezet kialakítása}

\section{Helyzetkép és lehetőség}

Általános, hogy a gyerekek berendezve, „készen” kapják az iskolai tanulótereket. A berendezést jó esetben a szülök segítik, de többnyire öket sem vonják be a pedagógusok a tervezés, berendezés folyamatába. A gyerekek véleményét, ötleteit meg teljesen elfelejtik megkérdezni. Tőlük ,idegen” - bár alsó tagozaton többnyire barátságos - tereket rendeznek be számukra, ahol az életük nagy részét töltik. A tanulói környezetet ráadásul szüken értelmezik a pedagógusok, vagyis többnyire csak a tanteremre vonatkoztatják. A folyosó, a mosdóhelyiség, az udvar közös kialakítására már nem figyelnek. Ha mégis szép az iskolaudvar, akkor kiderül, hogy a karbantartó tartja rendbe, s igazából csak a szünetben használják a gyerekek. Ezt tükrözi a legtöbb iskola udvara: aszfaltozott sportudvar, jobb esetben egy kis zöld felület is, néhány pad. Sajnos sok helyen pénzügyi gondokra hivatkozva bele sem kezdenek az inspiráló tanulóterek kialakításába. Pedig pénz nélkül is lehet csodát teremteni! A meglévő bútorok elmozdításával, egy paraván készítésével, amivel egy zugot is kialakíthatunk például egyéni vagy kiscsoportos munkához. Jól jön egy szőnyeg, amire leülhetnek a gyerekek, cserepes növények, amiket lehet gondozni. Egy madáritató tavacska, nyitott kertrész az udvaron, melyet akár egy projekt keretében hozhatunk létre, s a későbbiekben megfigyelésekre ösztönöz, közösen lehet gondozni. A gyerekekkel együtt megtervezett, berendezett külső-belső terek, melyek a gyerekek elképzelésének, igényének is megfelel, sokkal hatékonyabb. Maga a tervezés, berendezés is tanulás, ráadásul érzelmileg nagyobb biztonságot ad egy ilyen közösen kialakított tér. Oda jó bemenni, ott jó játszani, alkotni, elhúzódni. Mert a mienk. Közös. Ezért még a felelősségünk is megnő iránta, vagyis vigyázunk rá. 


\section{Javaslat}

A gyerekek, pedagógusok motiváltak legyenek saját tanulói környezetük kialakításában, higgyenek abban, hogy a közös tér kialakítása hozzájárul a jóllétünkhöz! Az inspiráló tanulótér kialakítását együtt kell megvalósítani: gyerekek, szülők, pedagógusok, iskolai munkatársak. Mindenki sajátjának fogja érezni, ha az ő igényének, elképzelésének is megfelelő a közösségi tér, mely a nyitott iskola tere is. Ki- és bejönnek az iskolába. a szülők, a helyi lakosok, a civil szervezetek képviselői, a fenntartó, más iskola látogatói. Hoznak, kínálnak együttmüködési lehetőségeket, s visznek jó gyakorlatokat, ötleteket. Az iskolát „használók” együtt álmodják meg az iskolájuk környezetét kívül-belül, s együtt formálják azt az igényeknek, életkori sajátosságoknak a figyelembe vételével. Egy tanulótér kialakítását célzó projekt visszafordíthatatlan kötődést jelent az iskolának. Inspiráló, tanuláshoz kedvező feltételeket teremtő hatása van.

\section{Valósághoz kötött tanulás}

\section{Helyzetkép és lehetőség}

A terepi, felfedező, valós problémákra megoldást kereső, valósághoz kötött tanulás még nem terjedt el. A gyerekekkel többnyire könyvböl, a könyv remélhetőleg jó - fotói alapján tanítják meg a pedagógusok, hogy néz ki egy-egy növény, pl. a bodza levele, termése. A padban ülve „tanulmányozzák” a bodzáról készült fotókat (!). Még akkor is így van ez sajnos, ha a közelükben megfigyelhető lenne a növény. Ha ez nem kötődik a valóságban megismert bodzához, vagyis sosem látták még közelröl ezt a növényt, akkor biztosak lehetünk abban, hogy a későbbiekben sem fogják felismerni. Az ismeretük átmeneti marad. Ráadásul egy „unalmas” órára ment el az idejük. Hogyan is lehetne másképp? Séta vagy kirándulás közben megnézhetnének a gyerekek egy bodzafát. Az évszaktól függően többféleképpen megvizsgálhatnák: levéllenyomatot készíthetnének, a bodza fájából medált, bodzapuskát, a bodza virágából üdítőitalt, a terméséből lekvárt fözhetnének, vagy gyapjút színezhetnének vele (kísérletezés után), de még Szép Ernő bodzáról szóló csodálatosan szép versét, az Olyan fehér-t is megtanulhatják, illusztrálhatják. Hogy mindezt mikor? Mindenre épülhet témanap, akár a bodzára is. De tanórákon, szakkörön, erdei iskolában is lehetőséget teremthetünk rá. Ha még bodzát is ültetünk az iskolaudvarra, akkor folyamatos lesz a gyerekek bodzával való „találkozása”!

Egy másik példa a kisiskolások babcsíráztatása, ami jó, de helyette még jobb lenne, ha saját veteményeskertet is alakítanának ki a gyerekek. Gondoznák a beleültetett/kifejlődött növényeket, s így a valóságban tapasztalnák meg, hogy mik az életfeltételek (pl. locsolni kell azokat, ha nem esik az eső, mert vízre van szükségük, egyébként elfonnyadnak, megfelelő hőmérsékleten, napfényen jobban fejlödnek). Azt is megtanulnák, milyen rovarok jelennek meg a kertben, s végül még a termést meg is ehetnék. Innen már csak ,egy ugrás”, hogy arról tanakodjunk, a helyi/hazai termékek vásárlása miért jobb. 


\section{Javaslat}

A gyerekekre figyelve, az általuk hozott örömökre, bánatokra, kérdésekre építve tervezzük meg, s építsük fel tudatosan a témaköreinket, amikkel foglalkozni fogunk. Jó karmesterként „csak” vezetni, irányítani kell a gyerekeket egy-egy helyzet megoldásakor, javaslatokat tenni, biztatni őket, s megteremteni a feltételeket a tanuláshoz. Ha „elbuknak”, akkor hagyni, hogy újra próbálkozzanak.

A terepi tanulásszervezése, a valóságos helyzetekre való építkezés valóban nagyobb szervezést, időt igényel. Ennek megfelelően nagyobb is a hozadéka! Ha a pedagógus tisztában van azzal, milyen célt szeretne elérni, akkor a célhoz érdemes a legmegfelelőbb utat, módszert kiválasztania.

\section{Környezetetika}

\section{Helyzetkép és lehetőség}

A természetre születésünk után természetes kíváncsisággal nézünk, nem félünk, nyitottan reagálunk minden rezdülésére. Ahogy növekedünk, úgy veszítjük el külső minták, hatások miatt harmonikus összhang iránti vágyunkat, természetes „bátorságunkat”.

Hogy milyen viselkedésformák lesznek ránk jellemzők, az is kisgyermekkorban alakul ki. A környezethez való viszonyulásunk - benne embertársaink elfogadása is - attól függ, milyen nevelést kaptunk. A szülői minták, később a pedagógusok által közvetített, őszinte értékrend adhatja meg a környezethez való kapcsolatunk „milyenségét”. Ezért fontos, hogy a pedagógusok tisztában legyenek saját szerepükkel, s felelősen vállalják a gyerekek nevelését.

Ismerünk neves, régen és ma élő tudósokat, természetvédőket, gondolkodókat, pedagógusokat, akik méltán lehetnek példaképek. Azok életútját, akik már nem élnek, kutatás alapján megismerhetik a tanulók. Pl. Xantus János, Hermann Ottó, Kaán Károly, Fekete István, Charles Darwin, Jacques-Yves Cousteau, Konrad Lorenz. Vitaestet rendezhetnek, felkeresheti azokat a helyszíneket, ahol megfordultak életükben, s megfejthetik, mi hatott rájuk leginkább. Kiállítást rendezhetnek a gyüjtött anyagokból. Érdemes megismertetni a gyerekekkel ma is élő, mintát adó, a fenntarthatóság nevelés, a természet megismerése érdekében sokat tevő embereket: pl. Vida Gábor, Csányi Vilmos, Schmidt Egon, David Attenborough, Jane Goodall, Al Gore. Egy-egy személyes találkozás, rövid beszélgetés, előadás ezekkel az emberekkel nagy elköteleződést válthat ki a gyerekekben a környezet- és természetvédelem iránt.

\section{Javaslat}

A gyerekek ismerjenek meg minél több olyan embert, életutat, amelyek példát mutathatnak, például a Földünkért érzett felelősségvállalásban. 


\section{Az infokommunikációs technológiák és a környezeti nevelés}

\section{Helyzetképes lehetőség}

Az oktatásfejlesztés egyik legfontosabb eszköze az infokommunikációs technológia, a világháló használata. A környezeti nevelés sem nélkülözheti a környezeti és egyéb helyi, regionális, országos és kontinentális adatbázisokat, azok tudományos hitelességű adatait. A világháló használata a diákokat bevezeti a globális összefüggések felismerésébe és az információk használatába. Néhány nemzetközi környezeti nevelési program is épít a digitális kompetenciára, például a Beagle projektek honlapja vagy a Carbon Detective projekt interaktív felülete.

A pedagógusok zöme koránál fogva „fél” ezeknek az eszközöknek a használatától. A generációs különbségek miatt gyakran tiltáshoz folyamodik. Pedig ez nem megoldás! A Z-generáció szülöttei beleszülettek ebbe a digitális korba, vagyis ezeknek az eszközöknek a használata nem jelent számukra problémát. A gond a korlátlan, mértéktelen használat lehet. Az okos, jó használat eléréséhez pedig a pedagógusok adhatnak inspiráló feladatokat, ötleteket. Például a tanulók készíthetnek számítógépen adatbázisokat, kiselőadásokat, internetes kutatást végezhetnek egy-egy témakörben, nemzetközi projektek interaktív felületét is használhatják, anyagokat tölthetnek fel és le, a terepen meghatározhatják egy-egy élöhely, érdekes faj koordinátáit (GPS). A terepen jó szolgálatot tehetnek az okos telefonra letölthető fajmeghatározást segítő anyagok. Ráadásul jó minőségű fotókat vagy éppen kisfilmet is tudnak készíteni a gyerekek. A közösségi kutatás szintén kiváló lehetőség a digitális eszközökkel való tanulásra, adatgyüjtésre. A Facebookra feltett kérdésre a diákok kapcsolathálójának nagyságától függően, a világ minden tájáról érkezhetnek válaszok. Bőséges adathalmaz elemzését kérhetjük a tanulóktól ennek alapján, így akár példák gyüjtését a hulladék megelőzésére, a biodiverzitás bizonyítására.

\section{Javaslat}

Ne tiltsuk, hanem „használjuk ki” ezen eszközök lehetőségeit, s építsük be a velük való munkavégzést a tanulás folyamatába! Ne szégyelljünk tanulni a diákoktól, s ne féljünk segítséget kérni tőlük!

\section{Egyéb hiányterületek}

Zöld Diákönkormányzat müködtetése (demokratikus döntéshozatalra, aktív állampolgárságra nevelés), idegen nyelv és a környezeti nevelés kapcsolata, Méltányos kereskedelem, Tudatos vásárlás, R4: Rethink, Reduce, Reuse and Recycle (Gondold át!/Előzd meg! Csökkentsd! Használd újra! Válogasd külön!)

\section{Összegzés}

A fenntarthatóság ,hiányterületei” nem idegenek számunkra. Ha nyitott szemmel, lélekkel figyelünk, akkor egyszerüen csak a létező, körülöttünk lévő világ „kihívásaira”, jelenségeire kell érzékenyen, jól reagálnunk. Ezek a „lehetőségek” 46 
adottak. Mivel minden embert, köztük a gyerekeket is „megszólítják” a valóságban látott, hallott örömök, problémák, így ha figyelünk rájuk, eleget vagyunk közöttük, akkor „meghalljuk”, mi az a témakör, ami foglalkoztatja őket, mi az, ami vonzó számukra.

A kreatív, szabadlelkü pedagógus bátran épít a gyerekekből fakadó érdeklődésre, s „használja ki” ezt, mint lehetőséget a saját foglalkozásainak megtervezésére, melyeken teret ad a tanulóknak. Ott tanulunk a legszívesebben, ahol számítanak ránk, ahol lehet kérdezni, kipróbálni, felfedezni, „csinálni” valamit. A szabad légkör feltétele a partnerség. A pedagógus nem a tudás birtokosa, hanem partner, társ a tanulás folyamatában. Ebben a helyzetben már lehet tévedni is, „merni” hibázni, s újra próbálkozni.

Az iskola, ha nyitott, akkor ,beengedi” azokat a lehetöségeket is, melyeket egy-egy meghívott szülö, mérnök, kutató, civil szervezet inspirál az adott helyi környezetre építve. Így teremthetünk alkalmat arra, hogy az iskola zárt közege helyett a világ kinyíljon, kitáguljon, élővé váljon, s a tanulás természetesen, szinte észrevétlenül történjen.

\section{Irodalom}

Az Európai Unió Tanácsa 2010. november 19-i következtetései a fenntartható fejlődést szolgáló oktatásról: (2010/C 327/05)

http://eur-lex.europa.eu/LexUriServ/LexUriServ.do?uri=OJ:C:2010:327:0011:0014:HU:PDF (letöltve: 2013. július 28.)

Néder Katalin, Saly Erika és dr. Szentpétery Lászlóné: Hazai és nemzetközi környezeti nevelési programok, projektek a közelmúltban http://tamop311.ofi.hu/szakmai-program/1-tema-okoiskola-program/okoiskola-nevelesi

Real World Learning Network projekt http://mkne.hu/projektek.php?projekt=17

Vásárhelyi Judit (1997, szerk.): Magyarország Öröm és Bánat Térképe, TermészetBúVÁR Alapítvány Kiadó, Budapest. 